\title{
Kontektualisasi Management Inventory Pangan Nasional Dalam Perspektif Islam*
}

\section{(CONTEXTUALIZATION NATIONAL FOOD INVENTORY MANAGEMENT IN ISLAMIC PERSPECTIVE)}

\author{
Maman Rahman Hakim \\ Magister Manajemen Universitas Muhammadiyah Jakarta \\ Jl. Ir. H. Juanda Ciputat \\ E-mail: maman.rahmanhakim@gmail.com
}

\begin{abstract}
The basic value of food security is the availability of food stocks and accessibility. Ironically, the increased production of food commodities in Indonesia is not matched with the proper stock management system, so as if Indonesia is experiencing a food crisis in the commodity. Institutional food stock management national scale in Indonesia there are at least two that Bulog and the Warehouse Receipt System. Qur'an as the Muslim holy book always irrelevant to solving the problems of social. To that end, the presence of the Koran to be the solution to provide instructions and guidance of life, one of them about food security problems associated with food stock management. In this paper will discuss how national institutional stock management in Indonesia, and how to contextualise the concept of national food stock management in the perspective of Islam. From both expected to provide a solution to the problem of food stock management in Indonesia.
\end{abstract}

Keywords: Stock Food, Bulog and Warehouse Receipt System, Islam

\begin{abstract}
Abstrak: Nilai dasar dari ketahanan pangan adalah ketersediaan stok pangan dan aksesibilitasnya. Ironisnya, meningkatnya produksi komuditas pangan di Indonesia tidak diimbangi dengan sistem manajemen stok yang tepat, sehingga seakan-akan Indonesia mengalami krisis pangan dikomuditas tersebut. Kelembagaan manajemen stok pangan skala nasional di Indonesia setidaknya terdapat dua yaitu Bulog dan Sistem Resi Gudang. Alquran sebagai kitab suci umat Islam selalu relevan untuk menjadi problem solving atas permasalahan sosial kemasyarakatan. Untuk itu, kehadiran Alquran menjadi solusi dengan memberikan petunjuk dan pedoman hidup, salah satunya tentang problem ketahanan pangan yang terkait dengan manajemen stok pangan. Dalam tulisan ini akan dibahas bagaimana kelembagaan manajemen stok nasional di Indonesia, dan bagaimana kontekstualisasi konsep manajemen stok pangan nasional dalam perspektif Islam. Dari keduanya diharapkan dapat memberikan solusi atas problem manajemen stok pangan di Indonesia.
\end{abstract}

Kata Kunci : Stok Pangan, Bulog dan Sistem Resi Gudang, Islam

* Diterima tanggal naskah diterima: 13 Februari 2015, direvisi: 24 Mei 2015, disetujui untuk terbit: 25 Juni 2015. 


\section{Pendahuluan}

Indonesia merupakan negara yang mempunyai keunggulan komparatif dan kompetitif disektor agraris. Sejarah telah membuktikan berbagai keunggulan sektor agraris Indonesia, keunggulan ini tidak terlepas dari kondisi alam indonesia yang gemah ripah loh jinawi. Baik iklim, tanah, udara, air, ragam kekayaan hasil bumi merupakan satu kesatuan terintegrasi yang menjadikan indonesia kaya akan hasil agraris. Bak sebongkah tanah yang terlempar dari surga, dengan kesuburan dan kekayaan hasil alam inilah yang menjadikan Indonesia diperebutkan pada masa kolonial oleh beberapa negara. Mulai dari Portugis hingga Jepang satu tujuannya yaitu untuk mengeruk kekayaan hasil alam Indonesia hanya untuk mempertahankan kehidupan dinegaranya masing-masing.

Fenomena laten yang terjadi pada sektor pangan nasional adalah adanya disparitas supply dan demand disetiap bulan dan musim yang sangat lebar. Disatu sisi pada saat musim panen raya supply akan bahan pangan melimpah sedangkan demand stabil dan sebaliknya ketika diluar musim panen supply berkurang bahkan menipis sedangkan demand tetap stabil. Harga komoditas pangan saat musim panen jatuh ambruk yang merugikan produsen dan harga melambung tinggi ketika diluar musim panen yang menjadikan para konsumen menjerit. Potensi kehilanggan atau loss bahan pangan akibat berlimpahnya pasokan ketika musim panen sangat tinggi bahkan tidak terdeteksi sehingga diluar musim panen pemerintah selalu menerapkan kebijakan impor untuk mengstasi persoalan kekurangan pasokan.

Sekarangpun, setelah sekian abad lamanya alam Indonesia diporsir kapasitas kemampuanya untuk menghidupi kebutuhan pangan masyarakat Indonesia pada khususnya dan masyarakat dunia pada umumnya masih tetap eksis dengan menyumbangkan berbagai bahan pangan yang tiap hari tidak ada putus-putusnya untuk rakyat Indonesia. Mulai dari beras, jagung, kedelai, garam, ikan, bawang merah dan sayur mayur lainya alam indonesia masih tetep mampu untuk memproduksi dan menghasilkan yang terbaik untuk memenuhi kebutuhan pangan Indonesia. Meskipun kalau melihat tingkat produktifitasnya tidak sehebat masa lalu.

Permasalahan yang ada dan yang terjadi pada Indonesia saat sekarang ini dengan alamnya yang gemah ripah loh jinawi tersebut adalah melemahnya ketahanan pangan. Fenomena melemahnya ketahanan pangan 
Indonesia dapat kita amati dewasa ini yang seringkali terjadi kelangkaan bahan pangan dan tingginya volume impor bahan pangan. Kelangkaan ini diakibatkan oleh fluktuasi pasokan yang kemudian menyebabkan fluktiasi harga yang melambung tinggi. Beras, cabai dan bawang merah adalah sedikit komuditas pangan yang saat ini mengalami krisis pasokan dan krisi harga.

Ketahanan pangan nasional sangat ditentukan oleh peningkatan laju pertumbuhan produksi pangan yang saat ini rata-rata negatif dan cenderung stagnan, sedangkan laju pertumbuhan penduduk selalu positif yang berarti bahwa kebutuhan terus meningkat. Ketersediaan total produksi dan kebutuhan nasional dari tahun ke tahun pada sektor pangan menunjukkan kesenjangan yang terus melebar. Hasil produksi pangan yang berbanding terbalik dengan tingkat konsumsi terus dibiarkan, maka akan menyebabkan resiko penambahan impor bahan pangan yang semakin besar dan berpengaruh terhadap ketahanan nasional dan kemandirian bangsa karena bangsa Indonesia akan semakin tergantung pada negara lain.

Inilah paradoks Indonesia, satu sisi sebagai bangsa yang gemah ripah loh jinawi dan pada sisi yang lain terancam dengan krisis pangan. Melihat kondisi yang seperti ini, dalam konteks keislaman sudah sepatutnya kita merenungkan bagaimana pola Islam mengatur pengelolaan pangan sebagai bahan yang komudidas yang mengauasai hajat hidup orang banyak. Dalam Islam terdapat ibroh dari kisah nabi Yusuf dalam mengelola stok pangan untuk mengantisipasi masa paceklik, yaitu dengan memproduksi pangan kemudian menyimpanya dalam gudang untuk jangka waktu masa paceklik tersebut.

Dalam konteks kekinian sistem manajemen stok pangan ala Nabi Yusuf mungkin dapat diterjemahkan pada sistem keindonesiaan yang ada saat ini dengan adanya Bulog sebagai pengendali harga dan pasokan beras dan juga pada sistem Resi gudang sebagai instrumen untuk mengatasi disparitas pasokan pada saat musim sehingga harga komuditas pada tinggat petani terjamin.

\section{Kondisi Makro Ketahanan Pangan Nasional}

Pangan merupakan kebutuhan dasar utama bagi manusia yang harus dipenuhi setiap saat. Hak untuk memperoleh pangan merupakan salah satu hak asasi manusia, sebagaimana tersebut dalam pasal 27 Undang-Undang 
Dasar 1945 maupun dalam Deklarasi Roma tahun 1996 tentang ketahanan pangan dunia. Sebagai kebutuhan dasar dan hak asasi manusia, pangan mempunyai arti dan peran yang sangat penting bagi kehidupan suatu bangsa. Perbandingan antara kurangnya ketersediaan pangan dengan makin meningkatnya kebutuhan, dapat menciptakan ketidakstabilan ekonomi maupun politik. Berbagai gejolak sosial dan politik dapat juga terjadi jika ketahanan pangan terganggu. Kondisi kritis ini bahkan dapat membahayakan stabilisasi nasional yang dapat meruntuhkan Pemerintah yang sedang berkuasa.

Pengalaman telah membuktikan bahwa gangguan pada ketahanan pangan seperti meroketnya kenaikan harga beras dan berbagai bahan pokok lainnya pada waktu krisis ekonomi 1997/1998, telah berkembang menjadi krisis multi dimensi, yang selanjutnya memicu kerawanan sosial yang membahayakan stabilitas ekonomi dan stabilitas nasional. Pangan memiliki pengaruh yang besar dalam bidang ekonomi berupa penyerapan tenaga kerja berbagai strata, pertumbuhan dan dinamika ekonomi, terjaganya lingkungan yaitu menjaga tata guna air dan udara bersih serta aspek sosial politik sebagai perekat bangsa, penjaga ketertiban dan keamanan masyarakat serta kemandirian bangsa.

Saat ini Jumlah penduduk Indonesia telah mencapai 240 juta jiwa dengan angka pertumbuhan $1,75 \%$ per tahun. Angka tersebut mengindikasikan besarnya kebutuhan pangan yang harus disediakan Pemerintah dalam bentuk produksi pangan nasional, cadangan pangan serta melalui impor pangan apabila dibutuhkan. Kebutuhan pangan yang sangat besar apabila tidak diimbangi peningkatan produksi pangan akan menghadapi permasalahan serius dalam bentuk kekurangan pangan, instabilitas nasional serta kesenjangan antara kebutuhan dan ketersediaan pangan nasional.

Ketahanan pangan nasional sangat ditentukan oleh peningkatan laju pertumbuhan produksi pangan yang saat ini rata-rata negatif dan cenderung menurun, sedangkan laju pertumbuhan penduduk selalu positif yang berarti bahwa kebutuhan terus meningkat. Ketersediaan total produksi dan kebutuhan nasional dari tahun ke tahun pada tiga komoditas pangan utama, yaitu padi, jagung dan kedelai menunjukkan kesenjangan yang terus melebar. Kesenjangan yang makin melebar terus dibiarkan, maka akan menyebabkan resiko penambahan impor bahan pangan yang semakin besar dan 
berpengaruh terhadap ketahanan nasional dan kemandirian bangsa karena bangsa Indonesia akan semakin tergantung pada negara lain.

Ketersediaan pangan nasional dan pengelolaannya pada setiap era pemerintahan menjadi salah satu prioritas utama pembangunan nasional. Kegiatan pengeloiaan pangan oleh Pemerintah seringkali mendapat kritik karena adanya ketidak-sempurnaan kegiatan yang diakibatkan oleh kebijakan sektoral, tumpang tindihnya kewenangan serta kurangnya koordinasi antar lembaga dan instansi Pemerintah. Permasalahan akibat kurang terkendalinya pengelolaan pangan, disebabkan kelemahan dalam proses penyusunan kebijakannya maupun karena akibat lain yang akan menimbulkan distorsi pasar. Intervensi dalam bentuk impor pangan dianggap rasional apabila dilakukan dalam keadaan defisit pangan atau jika infrastruktur pemasaran dan kelembagaan tidak cukup berkembang serta kompetitif untuk melindungi kepentingan produsen dan konsumen. Kemudahan mewujudkan ketersediaan pangan, stok pangan dunia yang tersedia serta kemungkinan alternatif bare bentuk program stabilisasi harga, mendorong berbagai pihak untuk selalu mengevaluasi kembali kebijakan pangan Pemerintah. Sebagai salah satu negara berkembang, Indonesia sejak lama telah menetapkan bahwa ketahanan pangan sebagai salah satu tujuan pembangunan nasional. Sampai sekarang pun, tujuan itu masih dilanjutkan seperti yang tat-Luang dalam RPPK (Revitalisasi Pertanian, Perikanan, dan Kehutanan) dan RPJM (Rancangan Pembangunan Jangka Menengah Nasional). Mengingat begitu banyaknya lembaga dan instansi Pemerintah yang terkait dengan ketahanan pangan, maka perlu langkah lanjutan yang berkaitan dengan pembentukan Dewan Ketahanan Pangan Nasional dalam bentuk aplikasi di lapangan agar dapat meningkatkan kemandirian bangsa. ${ }^{1}$

Ketahanan pangan merupakan salah satu isu paling strategis dalam pembangunan nasional, terlebih bagi negara berkembang seperti Indonesia yang berpenduduk besar. Perhatian terhadap ketahana pangan (food security) mutlak diperlukan karena terkait erat dengan ketahanan sosial (social security), stabilitas ekonomi, stabilitas politik dan keamanan atau ketahanan nasional (national security). Ketahanan pangan pada tinngkat nasional diartikan sebagai

1 Agus Setiadji, Implementasi Hubungan Kerja Antar Instansi Untuk Ketahanan Pangan Dapat Meningkatkan Kemandirian Bangsa, Lembaga Ketahana Nasional RI 2012. h 4-6 
kemampuan suatu bangsa untuk menjamin seluruh penduduknya memperoleh pangan yang cukup. ${ }^{2}$

Salah satu aspek penting dalam membangun ketahanan pagan adalah ketersediaan pangan dalam jumlah dan jenis yang cukup dan adanya sistem kelembagaan dimasyarakat dalam pengelolaan pangan. Ketersediaan pangan dibangun melalui peningkatan kemampuan produksi, peningkatan pengelolaan stok pangan, serta distribusi pangan untuk mengisi kesenjangan antara daerah dalam aspek produksi dan kebutuhan.

Ketahanan pangan dihasilkan oleh suatu sistem pangan yang terdiri atas tiga subsitem, yaitu : (1) Ketersediaan pangan dalam jumlah dan jenis yang cukup untuk seluruh penduduk, (2) Distribusi pangan yang lancar dan merata, (3) Konsumsi pangan setiap individu yang memenuhi kecukupan gizi dan kaidah kesehatan.

Ketersediaan stok pangan dibangun melalui peningkatan kemampuan produksi di dalam negeri, peningkatan pengelolaan cadangan serta impor untuk mengisi kesenjangan antara produksi dan kebutuhan.

Data kondisi pangan nasional dari beberapa komuditas utama

1. Beras

\begin{tabular}{|c|c|c|c|c|c|c|}
\hline \multirow[t]{2}{*}{ Tahun } & \multirow{2}{*}{$\begin{array}{c}\text { Konsumsi } \\
\text { (000 ton) }\end{array}$} & \multirow{2}{*}{$\begin{array}{l}\text { Produksi } \\
\text { (000 ton) }\end{array}$} & \multirow{2}{*}{$\begin{array}{l}\text { Ekspor } \\
\text { (ton) }\end{array}$} & \multirow{2}{*}{$\begin{array}{l}\text { Impor } \\
\text { (ton) }\end{array}$} & \multicolumn{2}{|c|}{ Surplus/Defisit } \\
\hline & & & & & Ribu Ton & $\%$ \\
\hline 2010 & 33.068 & 37.396 & 345 & 686.108 & $4.301,3$ & 11,51 \\
\hline 2011 & 33.056 & 36.968 & 1.062 & 2.686 .990 & $3.912,1$ & 10,58 \\
\hline 2012 & 33.047 & 38.823 & 1.091 & 1.924 .563 & 5.776 .2 & 14,88 \\
\hline \multicolumn{7}{|c|}{ 2. Jagung } \\
\hline \multirow[t]{2}{*}{ Tahun } & Konsumsi & Produksi & Ekspor & Impor & \multicolumn{2}{|c|}{ Surplus/Defisit } \\
\hline & (000 ton) & (000 ton) & & (ton) & Ribu Ton & $\%$ \\
\hline 2010 & 20.066 & 18.328 & 41.954 & 1.527 .516 & -1.738 & $-9,48$ \\
\hline 2011 & 20.505 & 17.230 & 30.787 & 2.858 .174 & -3.275 & $-19,01$ \\
\hline 2012 & 20.392 & 19.377 & 70.741 & 1.889 .431 & -1.015 & $-5,24$ \\
\hline
\end{tabular}

${ }^{2}$ Muchjidin Rahmat dkk, Kajian Sistem Cadangan Pangan Masyarakat Perdesaan Untuk Mengurangi 25\% Resiko Kerawanan Pangan, Balitbang Deptan RI.2010. hal 1 
3. Kedelai

\begin{tabular}{ccccccc}
\hline \multirow{2}{*}{ Tahun } & Konsumsi & Produksi & \multirow{2}{*}{$\begin{array}{c}\text { Ekspor } \\
\text { (ton) }\end{array}$} & $\begin{array}{c}\text { Impor } \\
\text { (ton) }\end{array}$ & \multicolumn{2}{c}{ Defisit } \\
\cline { 6 - 8 } & (000 ton) & (000 ton) & & Ribu Ton & $\%$ \\
\hline 2010 & 2.353 & 907 & 385 & 1.740 .987 & 1.446 & 159,43 \\
2011 & 2.489 & 870 & 523 & 1.911 .987 & 1.619 & 186,09 \\
2012 & 2.946 & 852 & 33.950 & 2.128 .763 & 2.094 & 245,77
\end{tabular}

4. Daging sapi

\begin{tabular}{cccccccc}
\hline \multirow{2}{*}{ Tahun } & Konsumsi & Produksi & \multirow{2}{*}{$\begin{array}{c}\text { Ekspor } \\
\text { (ton) }\end{array}$} & Impor & \multicolumn{2}{c}{ Defisit } \\
\cline { 6 - 7 } & (000 ton) & (000 ton) & & Ribu Ton & $\%$ \\
\hline 2010 & 440.774 & 349.967 & 0 & 4.322 & 90.807 & 25,95 \\
2011 & 488.931 & 410.698 & 0 & 3.598 & 78.233 & 19,05 \\
2012 & 544.896 & 425.495 & 2 & 39.419 & 119.401 & 28,06 \\
\hline
\end{tabular}

5. Cabai

\begin{tabular}{ccccccc}
\hline \multirow{2}{*}{ Tahun } & Konsumsi & Produksi & \multirow{2}{*}{$\begin{array}{c}\text { Ekspor } \\
\text { (ton) }\end{array}$} & $\begin{array}{c}\text { Impor } \\
\text { (ton) }\end{array}$ & \multicolumn{2}{c}{ Surplus } \\
\cline { 6 - 8 } & (000 ton) & (000 ton) & & Ribu Ton & $\%$ \\
\hline 2010 & 672.35 & $1.483,08$ & $1.229,1$ & $1.798,1$ & 830,78 & 56,02 \\
2011 & 769.55 & $1.656,62$ & 826,4 & 620,1 & 887,06 & 53,55 \\
2012 & 688.29 & $1.380,07$ & $9.986,2$ & $26.838,7$ & 691,78 & 49,16 \\
\hline
\end{tabular}

6. Bawang Merah

\begin{tabular}{ccccccc}
\hline \multirow{2}{*}{ Tahun } & Konsumsi & Produksi & Ekspor & Impor & \multicolumn{2}{c}{ Surplus } \\
\cline { 6 - 7 } & (000 ton) & (000 ton) & (ton) & (ton) & Ribu Ton & $\%$ \\
\hline 2010 & 601.887 & 1.048 .934 & 19.085 & 122.191 & 447.047 & \\
2011 & 568.850 & 839.124 & 8.042 & 117.627 & 324.274 & \\
2012 & 695.128 & 960.072 & 30 & 70.952 & 264.944 & \\
\hline
\end{tabular}

Sumber: RPJMN Bidang Pangan dan Pertanian 2015-2019, Bappenas RI 2013

83 - Fakultas Agama Islam Universitas Ibn Khaldun Bogor 
Kondisi ketahanan pangan Indonesia dalam setiap tahunya dapat dilihat dari data diatas. Baik pertumbuhan produksi, pertumbuhan ekspor nasional komuditas pangan serta konsumsi nasional masyarakat Indonesia. Kesiapan Indonesia jika dilihat dari aspek pertumbuhan produksi pangan pada beberapa komuditas sangat menghawatirkan. Kondisi darurat pangan terjadi pada komuditas jagung, kedelai dan daging sapi. Berdasarkan data di atas ketahanan pangan Indonesia pada komuditas jangung mengalai defisit rata-rata $10 \%$ pertahun, Daging sapi $24 \%$ pertahun serta jagung $196 \%$ pertahun. Produksi padahal selalu menunjukan tren positif, hanya pada komuditas kedelai yang tiap tahunya malah menurun tren produksinya. Pertumbuhan ledakan penduduk nampaknya tidak mampu diatasi dengan tren produksi yang dicapai karena pertumbuhanya tidak berbanding lurus. Padahal kalau melihat sumber daya yang mendukungnya potensi untuk mengembangkan komuditas tersebut agar bisa swasembada sangat memungkinkan. Sumber daya petani, lahan maupun pasar sangat terbuka lebar. Lagi-lagi ini tergantung bagaimana political wiil pemerintah dalam membuat dan mengambil kebijakan untuk mengoptimalkan sumber daya yang ada untuk mendukung terciptanya swasembada komuditas yang stoknya masih defisit sehingga dapat mengurangi impor.

Lain lagi dengan kondisi riil beras, cabai dan bawang merah seperti yang tertera dalam data diatas dibeberapa data komuditas masih ada yang kontradiktif. Antara volume produksi dalam negeri dan volume konsumsi (kebutuhan) dilihat secara data sudah mencukupi bahkan berlebih tetapi anehnya masih melakukan impor yang seakan-akan kebutuhan dalam negeri masih kekurangan. Dari data diatas bisa dilihat bagaimana pertumbuhan produksi komuditas beras, cabai dan bawang merah, hampir trenya selalu meningkat positif

Pertumbuhan produksi padi bisa dikatakan sudah swasembada bahkan di tahun 2010 sampai 2012 mengalami surplus $12 \%$ dari total konsumsi. Cabai merah juga dari tahun 2010 sampai 2012 mengalami surlpus rata 52,91\% pertahun. Demikian juga dengan bawang merah di periode yang sama mengalami surplus rata-rata $30 \%$ pertahun. Sayangnya dari kondisi surplus yang sedemikian tinggi nyatanya indonesia masih rajin melakukan impor pada tiga komuditas tersebut. Ini adalah kondisi yang kurang masuk akal kalau dilihat dari perspektif ekonomi. 
Pola produksi beberapa komuditas pokok seperti beras, cabai, bawang merah di Indonesia yang dilakukan oleh petani adalah dengan menyesuaikan iklim. Hal ini dilakukan untuk mengurangi biaya produksi, meminimalisir serangan hama dan resiko gagal panen. Pola produksi yang seperti inilah yang akhirnya menyebabkan terjadinya disparitas pasokan dan panen disetiap bulan. Pada bulan-bulan tertentu panen raya terjadi sehingga pasokan melimpah berlebih dan kadang terbuang sia-sia dan dibulan-bulan yang lain pasokan berkurang karenan tiodak ada panen. Seperti bulan bulan April sampai Mei ini adalah masa panen raya padi, Bulan Juni -Juli adalah musim panen raya pertama bawang merah dan bulan September sampai Oktober musim panen raya tahap kedua bawang merah. Di luar bulan-bulan tersebutlah pasokan berkurang karena bukan musim panen komuditas tersebut. Inilah yang menyebabkan harga melambung tinggi sehingga kadang pemerintah mengambil kebijakan impor untuk mengatasi kekurangan pasokan.

Kondisi seperti itu hampir setiap tahun terjadi di Indonesia. Panen raya bagi Pemerintah dan konsumen tentunya hal yang sangat menggembirakan, tetapi karena tidak ada regulasi yang tepat tidak jarang petani mengeluh bahkan aksi demo pun kadang dilakukan untuk meminta kebijakan harga, karena setiap panen raya harga komuditas jatuh, ironis memang. Keadaan sebalikya bisa terjadi pada saat musim paceklik (bukan musim panen raya) dimana harga komuditas pangan bisa meroket tinggi, konsumen menjerit dan pemerintahpun kalang kabut. Seperti yang terjadi pada saat ini harga beras dan bawang merah melambung tinggi yang bagi konsumen sangat memberatkan.

Pemerintah dan stakeholder perpanganan sudah seharusnya berfikir mencari solusi yang komprehensif untuk mengatasi kondisi laten yang hampir tiap tahun terjadi ini. Disparitas antara pasokan dan kebutuhan komuditas pangan yang merepotkan ini tentunya bukan hanya cukup diatasi dengan operasi pasar, dengan menggelontorkan subsidi atau bantuan raskin yang hanya bersifat semu dan sementara. Karenanya, bagaimana pola untuk mengatur agar stok pangan yang berlebih saat musim panen tidak terbuang dengan menerapkan pola manajemen persediaan (stok) menjadi sebuah keniscayaan yang harus direalisasikan lebih massif dan intensif.

Hal ini dilakukan dengan tujuan untuk menyediakan jumlah persediaan yang tepat, lead time yang tepat dan biaya rendah. Biaya 
persediaan merupakan keseluruhan biaya operasi dan sistem persediaan. Perusahaan dalam ha ini pemerintah perlu mengadakan analisis untuk menentukan tingkat persediaan yang dapat meminimumkan biaya atau paling ekonomis, ${ }^{3}$ sehingga kondisi laten yang terjadi pada persoalan pangan dapat diminimalisir. Selain Tujuan tersebut juga dengan adanya dari manajemen persediaan adalah memiliki persediaan dalam jumlah yang tepat, pada waktu yang tepat dan dengan biaya yang trendah. ${ }^{4}$

\section{Kelembagaan Dan Instrumen Manajemen Persediaan Pangan Di Indonesia}

Persediaan adalah barang yang dimiliki untuk dijual atau untuk diproses selanjutnya dijual. Berdasarkan pengertian di atas maka perusahaan jasa tidak memiliki persediaan, perusahaaan dagang hanya memiliki persediaan barang dagang sedangkan perusahaan industri memiliki 3 jenis persediaan yaitu persediaan bahan baku, persediaan barang dalam proses dan persediaan barang jadi (siap untuk dijual). ${ }^{5}$

Manajemen persediaan (inventory management) atau pengendalian tingkat persediaan adalah kegiatan yang berhubungan dengan perencanaan, pelaksanaan dan pengawasan penentuan kebutuhan pokok, sehingga kebutuhan produk dapat dipenuhi pada waktunya dan dilain pihak investasi persediaan produk dapat ditekan secara optimal. Pengendalian tingkat persediaan bertujuan mencapai efisiensi dan efektifitas optimal dalam penyediaan produk. Usaha yang perlu dilakukan dalam manajemen persediaan secara garis besar dapat diperinci sebagai berikut: (1)Menjamin terpenuhinya kebutuhan produk. (2) Membatasi nilai seluruh investasi; (3)Membatasi jenis dan jumlah produk; (4)Memanfaatkan seoptimal mungkin produk yang ada

Penangana persediaan barang haruslah dianut prinsip pengelolaan persediaan, yakni penentuan jumlah dan jenis barang yang disimpan dalam

${ }^{3}$ Yamit, Zulian. Manajemen Persediaan. Yogyakarta : Ekonisia, 2005, h. 8

${ }^{4}$ Ishak, Aulia, Manajemen Operasi, yogyakarta : Graha Ilmu, 2010, h.164

${ }^{5}$ Achun, Persediaan. http://zulidamel.wordpress.com/2008/01/02/persediaan/2008, diakses tanggal 21 Maret 2015 
persediaan haruslah sedemikian rupa sehingga oiperasi perusahaan tidak terganggu. ${ }^{6}$

Definisi lain dari persediaan adalah sebagai stock bahan baku yang digunakan untuk memfasilitasi operasi atau untuk memuaskan permintaan konsumen. Jenis persediaan meliputi; bahan baku, barang dalam proses dan barang jadi. Definisi tersebut mengacu pada proses transformasi operasi, sehingga dapat dijelaskan proses aliran bulan dengan persediaan bahan menunggu memasuki proses produksi. Persediaan dalam proses merupakan tahap menengah pada transformasi dan persediaan barang jadi siap melengkapi transformasi dalam sistem produksi. ${ }^{7}$

Persediaan juga dapat diartikan sebagai suatu aktiva yang meliputi barang-barang milik perusahaan dengan maksud untuk dijual suatu periode usaha yang normal, atau persediaan barang yang masih dalam pengerjaan, proses produksi dan persediaan barang baku yang menunggu penggunaanya dalam suatu proses produksi. ${ }^{8} \quad$ Sedangkan sistem persediaan adalah serangkaian kebijaksanaan dan pengendalian yang memonitor tingkat persediaan dan menentukan tingkat persediaan yang harus dijaga, kapan persediaan harus diisi, dan berapa besar pesanan yang harus dilakukan. Sistem ini bertujuan menetapkan dan menjamin tersedianya sumber daya yang tepat, dalam kuantitas yang tepat dan pada waktu yang tepat. ${ }^{9}$

\section{Fungsi-Fungsi Persediaan}

Bahwa efisiensi operasional suatu organisasi dapat ditingkatkan karena berbagai fungsi penting persediaan. Pertama harus diingat bahwa persediaan adalah sekumpulan produk phisikal pada perbagai tahap proses transformasi dari bahan mentah ke barang dalam proses dan kemudian

${ }^{6}$ Indrajit, E,R dan Djopkopranoto.R. Manajemen Persediaan, jakarta : Grasindo.2003, h.

$4-5$

${ }^{7}$ Zulfikarijah, Fien, Manajemen Persediaan, malang : Universitas Muhammadiah Malah press, 2005, h. 4

${ }^{8}$ Assauri, sofjan. Manajemen Produksi dan Operasi, Jakarta : Fakultas Ekonomi Universitas Indonesi, 2004. h.169-170

9 Zulfikarijah, Fien, Manajemen Persediaan, malang : Universitas Muhammadiah Malah press, 2005, h. 4 
barang jadi. Persediaan ini mungkin tetap tinggal diruang penyimpanan, gudang, pabrik atautoko-toko pengecer. Fungsi-fungsi persediaan tersebut antara lain :

1. Fungsi decoupling

Fungsi penting persediaan adalah memungkinkan operasi-operasi perusahaan internal dan eksternal mempunyai kebebasan. Persediaan decouples ini memungkinkan perusahaan dapat memenuhi permintaan langganan tanpa tergantung pada supplier.

2. Fungsi Antisipasi

Untuk menghadapi fluktuasi permintaan yang dapat diperkirakan dan diramalkan berdasar pengalaman atau data-data masa lalu, yaitu permintaan musiman. Hal ini perusahaan dapat mengadakan persediaan musiman (seasonal inventories).

Perusahaan juga sering menghadapi ketidakpastian jangka waktu pengiriman dan permintaan akan barang-barang selama peroide persamaan kembali, sehingga memerlukan kuantitas persediaan ekstrayang sering disebut persediaan poengaman (safety inventories). Persediaan pengaman merupakan pelengkap fungsi decoupling yang telah diuraikan di atas. Persediaan antisipasi ini penting agar proses produksi tidak terganggu. ${ }^{10}$

Dalam konteks kenegaraan maka manajemen persediaan pangan berarti kemampuan pemerintah dalam menerapkan sistem pengelolaan pangan mulai dari hulu sampai hilir, mulai dari produksi samapi distribusi dalam rangka menjaga ketahanan dan kestabilan pasokan pangan untuk warga negaranya.

Konsep ketahanan pangan merupakan fenomena yang kompleks, mencakup banyak aspek dan faktor terkait yang luas. Isu ketahanan pangan mengemuka sejak tahun 1970-an seiringan dengan terjadinya krisis pangan global. Negara yang penduduknya mengalami kelaparan akibat krisi pangan dianggap tidak mempunyai ketahanan pangan. Oleh sebab itu, konsep

${ }^{10}$ Handoko, T Hani, Dasar-Dasar Manajeman Produksi dan operasi, Yogyakarta : BPFE, 2000, h. 335 
ketahanan pangan pada masa tersebut lebih banyak membahas ketersediaan (stok) pangan pada tingkat nasional dan global. ${ }^{11}$

Tantangan pangan Indonesia semakin hari semakin kompleks. Pada satu sisi, peningkatan permintaan bahan pangan terus terjadi seiring dengan semakin meningkatnya jumlah penduduk serta meningkatnya daya beli dan selera masyarakat akan bahan pangan. Menurut draft RUU sebagai pengganti Undang- Undang nomor 7 tahun 1996 tentang pangan, kemandirian pangan diartikan sebagai kemampuan produksi pangan dalam negeri yang didukung kelembagaan ketahanan pangan, yang mampu menjamin pemenuhan kebutuhan yang cukup ditingkat individu.

Pembahasan konsep ketahanan pangan tidak terlepas bagaimana konsep manajemen stok (cadangan) pangan itu sendiri. Di Indonesia peraturan formal Undang-undang Nomor 7 tahun 1996 tentang pangan pasal 47 menyebutkan bahwa pengelolaan cadangan pangan nasional menjadi tanggung jawab pemerintah dan masyarakat. Hal ini berarti bahwa keberadaan pangan pemerintah tidak menghapuskan pentingnya cadangan pangan masyarakat harus sama-sama eksis.

Implementasi kelembagaan dari Undang-undang Nomor 7 tahun 1996 tentang pangan pasal 47 setidaknya saat ini terdapat satu lembaga dan satu instrumen yang konsen dalam manajemen stok pangan dalam rangka menjaga ketahanan pangan nasional. Satu lembaga dan satu instrumen tersebut adalah Perum Bulog dan Sistem Resi Gudang. Perum Bolog adalah salah satu bentuk campur tangan pemerintah dalam memanjemen stok pangan sedangkan Resi Gudang adalah sistem manajemen stok pangan yang menuntut peran aktif masyarakat.

\section{Pertama, Bulog}

Terkait dengan aspek pengelolaan dan pemeliharaan cadangan pangan nasional, Peraturan pemerintah (PP) No. 68 tahun 2002 menyebutkan secara tegas pentingnya peran pemerintah provinsi, kabupaten dan pemerintah desa dalam menangani masalah persediaan pangan. Cadangan

${ }^{11}$ Handewi P.S. Rahman dkk, Kebijakan Pengelolaan Cadangan Pangan Pada Era Otonomi Daerah dan Perum Bulog. Forum Penelitian Agro Ekonimi IPB. 2005, h.74 
pangan merupakan salah satu sumber persediaan pangan yang penting, sebagai lembaga penyangga persediaan pangan nasional, Sebelum perubahan Bulog menjadi Perum, Bulog memiliki peran sentral dalam mengelola persediaan pangan nasional. Secara implisit Bulog diharuskan membuat kebijakan yang tidak berpihak pada konsumen, sekaligus tidak merugikan konsumen. ${ }^{12}$

Dalam operasionalnya, pelaksanaan tugas tersebut mencakup aspek bisnis dan sekaligus terdapat misi sosial. Apabila kedua fungsi tidak dapat dipadukan secara harmoni maka Bulog akan dibenci konsumen bila berpihak kepada produsen dan sebalaiknya akan dibenci produsen apabila berpihak kepada konsumen.

Seperti diketahui, sejak bulan Mei 2003 berdasarkan PP No. 72003 tentang pembentukan Perum Bulog, lembaga penyangga pangan nasional yaitu Badan Urusan Logistik (Bulog) yang semula berstatus sebagai LPND (Lembaga Pemerintah Non departeman) telah berubah status menjadi Perum Bulog. Perubahan ini membawa konsekwensi terjhadap tugas, mandat dan kewenangan Bulog dalam penyelenggaraan dan pengelolaan ketahanan pangan nasioanal.

Apabila dicermati, perubahan status Bulog dari LPND menjadi Perum menyebabkan hilangnya dua hal yang sangat penting yaitu (1) hilangnya komitmen nasional dalam penanganan komudiotas strategis dan (2) hilangnya kelembagaan pemerintah secara nasional yang ditugaskan untuk menangani komuditas strategis tersebut secara terintegrasi ${ }^{13}$. Komitmen nasional pada saat Bulog sebagai LPND tertulis secara tegas dalam tugas pokok Bulog, yaitu untuk (1) mengendalikan harga untuk melindungi produsen dan konsumen dan (2) membina ketersediaan, keamanan dan pembinaan mutu gabah, beras, gula, gandum, terigu, bungkil, kedelai serta bahan pangan dan bahan pakan lainnya, baik secara langsung maupun tidak langsung. ${ }^{14}$ Uraian dari tugas pokok Bulog tersebut menunjukan adanya komitmen nasional untuk memperlakukan beberapa komiuditas terpilih sebagai komuditas pangan strategis nasional.

\footnotetext{
${ }_{12}$ Amang, B. Dan H.M. sawit. Kebijakan Beras dan pangan Nasional : Pelajaran Orde baru dan Orde Reformasi, Bogor: IPB Pres,2001.

13 basuki 2004

${ }^{14}$ Bulog, Bulog Baru menyelaraskan Kegiatan dan Memantapkan Tugas nasional, Bulog: Jakarta. 2003.
} 
Peraturan Pemerintah (PP) No 68 Tahun 2002 tentang Ketahanan Pangan telah mengamanatkan bahwa Indonesia harus memperkuat cadangan pangan. Di sana disebutkan cadangan beras pemerintah (CBP), yang sebenarnya merupakan manifestasi dari konsep stok besi (iron stock) atau cadangan yang harus ada sepanjang waktu, terutama untuk mengatasi kondisi darurat. Stok besi ini yang aman minimal setara dengan satu bulan total konsumsi, atau sekitar 300.000 ton. Selain itu, cadangan pangan pokok juga perlu disimpan dalam bentuk stok penyangga (buffer stock) untuk pengendalian gejolak harga, dalam skema operasi pasar. Perum Bulog kini mengelola CBP dan stok penyangga, terutama guna menjalankan program beras untuk keluarga miskin (raskin). Apabila saat ini Bulog hanya mampu melakukan pengadaan beras dalam negeri sebanyak 2 juta ton lebih, itu adalah batas bawah tingkat aman untuk mengantisipasi gejolak peningkatan harga, terutama pada musim paceklik. Kapasitas gudang Bulog di seluruh Indonesia mencapai 4 juta ton lebih, sehingga strategi pengadaan pangan (dari) dalam negeri perlu memperoleh perhatian yang memadai.

Apabila kekuatan Bulog hanya 7\% dari total produksi beras di dalam negeri, berarti sebagian besar stok pangan di Indonesia itu dikelola masyarakat sendiri (dan pedagang). Secara legal, Undang-Undang Nomor 7 Tahun 1996 tentang Pangan telah mengamanatkan bahwa masyarakat dan pemerintah memelihara cadangan pangan yang bersifat pokok. Kata kuncinya, pemerintah dan pemerintah daerah (plus masyarakat) perlu bahumembahu meningkatkan cadangan pangan demi terciptanya ketahanan pangan, bahkan kemandirian pangan, di Indonesia. Upaya pengelolaan cadangan pangan oleh pemerintah daerah dapat menjadi komplemen dari CBP di tingkat pusat (yang umumnya dikelola Perum Bulog). Prasyarat, kriteria, dan indikator untuk mewujudkan cadangan pangan regional ini memang perlu dirumuskan, guna meminimalisasi upaya perburuan rente dari para petualang. ${ }^{15}$

Perlu disebutkan bahwa aktifitas ekonomi pangan di indonesia secara prinsip dijalankan berdasarkan meklanisme pasar bebas. Konsekuensinya, pedagang menguasai cadangan pangan paling besar dibandingakan dengan pemerintah dan rumah tangga. Walaupun demikian perlu digarisbawahi

15 Riswani, Strategi dan Manajemen Pengelolaan Cadangan Pangan Nasional, Prosiding Seminar Nasional, Jurusan Sosial Ekonomi Pertanian Fakultas Pertanian Universitas Sriwijaya, 2010. h. $1762-1763$ 
bahwa pembangunan ketahanan pangan tidak dapat sepenuhnya diserahkan kepada mekanisme pasar bebas. Argumentasinya, apabila terjadi kelebihan permintaan (exess demand) yang dicirikan berkurangnya pasokan barang dan harga bahan pangan melambung tinggi, maka mekanisme pasar bebas membutiuhkan waktu relatif lama untuk kembali kepada kondisi keseimbangan semula. Padahal perwujudan ketahanan pangan yang mantap mensyaratkan bahwa pangan harus tersedia setiap saat dengan jumlah yang cukup serta dengan harga yang terjangkau bagi masyarakat.

Mengingat pembangunan ketahana pangan tidak mungkin sepenuhnya diserahkan pada mekanisme pasar bebas, maka keberadaan persediaan pangan pemerintah menjadi sangat urgen. Justifikasinya, dengan menguasai persediaan pangan maka apabila sewaktu-waktu excess demand pemerintah dengan segera dapat melakukan intervensi pasar misalnya melalui operasi pasar guna menjamin terwujudnya harga yang stabil. ${ }^{16}$

Yang menjadi masalah adalah saat ini Bulog hanya berkutat menangani stok pangan hanya pada satu komoditas yitu beras. Sedangkan komuditas pangan starategis lainya seperti kedelai, jagung, garam, bawang merah, cabai dan lain sebagainya belum tercover dalam tugas pokok Bulog. Karenanya, kedepan diharapkan Bulog juga berperan dalam kebijakan intervensi bahan pangan strategis lainya.

\section{Kedua, Resi Gudang}

Resi gudang atau dalam bahasa asing disebut sebagai warehouse receipt system (WRS) adalah dokumen bukti kepemilikan barang yang disimpan di suatu gudang yang diterbitkan oleh pengelola gudang dan merupakan sekuriti yang menjadi instrumen perdagangan serta merupakan bagian dari sistem pemasaran dan keuangan dari banyak negara industri. ${ }^{17}$ Dalam konteks ini gudang memiliki pengertian bermacam-macam, tergantung komuditas yang disimpan, mulai dari padi, beras, jagung, kedelai, cokelat,

${ }^{16}$ Handewi P.S. Rahman dkk, Kebijakan Pengelolaan Cadangan pangan Pada era

Otonomi Daerah dan Perum Bulog. Forum Penelitian Agro Ekonimi IPB. 2005, h.78

17 Wikipedia, Resi Gudang, http://id.wikipedia.org/wiki/Resi Gudang/20/3/2015. 
kopi, minyak sawit hingga garam. Resi gudang ini nantinya bisa digunakan sebagai jaminan atas kredit dari perbankan. ${ }^{18}$

Secara lebih spesifik untuk sektor pertanian, SRG merupakan bukti kepemilikan atas barang yang disimpan oleh petani di gudang (Document of Title) yang dapat dialihkan, diperjualbelikan bahkan dijadikan agunan tanpa perlu persyaratan agunan lain. ${ }^{19}$ Oleh karena resi gudang merupakan instrumen surat berharga maka resi gudang ini dapat diperdagangkan, diperjualbelikan, dipertukarkan ataupun digunakan sebaghai jaminan bagi pinjaman.

UU No. 9 tahun 2006 mengenai Sistem Resi Gudang telah disahkan pada tanggal 14 Juli 2006 dan telah menjadi bagian penting dari program pengembangan ekonomi lokal dalam Rencana Pembangunan Jangka Menengah tahun 2004-2009 Departemen Perdagangan. UU tentang SRG merupakan terobosan baru yang melengkapi hukum penjaminan yang berlaku di Indonesia seperti gadai dan jaminan fidusia. Dalam sistem resi gudang yang menjadi objek jaminan adalah resi gudang di mana penguasaan terhadap barang berada ditangan pengelola gudang. Pada tanggal 22 Juni 2007 pemerintah telah pula menerbitkan peraturan pemerintah nomor 36 tahun 2007 tentang resi gudang untuk melaksanakan ketentuan dalam undang-undang nomor 9 tahun 2006 tersebut.

Penerapan resi gudang pada dasarnya dilatarbelakangi fenomena turunya harga pada komuditas pertanian pada saat panen raya, sudah menjadi permasalahan laten yang seringkali merugikan petani. Terus berulangnya permasalahan tersebut, baik dalam durasi musiman, tahunan maupun siklus sekian tahun sekali, seolah-olah membuat petani tidak berdaya menghadapinya. Secara umum hampir semua komuditas baik tanaman pangan, hortikultura maupun perkebunan dan komuditas pangan lainya

\footnotetext{
18 Ashari. Prospek Sistem Resi Gudang (SRG) Sebagai Alternatif Pembiayaan Sektor Pertanian, Balitbang Kementan RI, 2010, h.4

${ }^{19}$ Komoditas atau barang yang dimaskud dalam UU dan peraturan SRG adalah setiap barang yang bergerak yang dapat disimpan dalam jangka waktu tertentu dan dapat diperdagangkan secara umum dan paling sedikit memenuhi persyaratan antyara lain : (1). Memiliki daya simpan paling sedikit tiga bulan, (2). Memenuhi standar mutu tertentu dan (3) jumlah minimum barang yang disimpan. Per tahun 2015 setidaknya sudah ada 11 komoditas pertanian sebagai barang yang dapat disimpan di gudang dalam penyelenggaraan sistem resi gudang. Komoditas tersebut adalah : Gabah, beras, kopi, kakao, lada, karet, rumput laut, jagung, kedelai, garam dan rotan.
} 
mengalami nasib yang sama. Untuk menghindari kerugian akibat turunya harga saat panen raya, secara teori petani dapat melakukan tunda jual. Namun hal tersebut tidak mudah dilakukan karena petani memerlukan uang tunai secara segera, baik untuk modal tanam berikutnya ataupun untuk memenuhi kebutuhan hidup rumah tangga. Terjadinya permasalahan turunya harga, jika dirunut akar permasalahanya terjadi akibat pola produksi dan konsumsi komoditas pertanian yang tidak matching antara jumalah pasoakan dan kebutuhan pada suatu waktu tertentu. Pada saat musim panen raya, supply melimpah yang mengakibatkan turunya harga dan sebaliknya pada saat paceklik harga komoditas melambung tinggi hingga kadang tak terjangkau. Kondisi ini tentu memerlukan penanganan yang lebih baik lagi dimasa mendatang, terutama pembenahan pada aspek manajemen pola tanam dan manajemen stok yang hingga saat ini masih berjalan secara optimal. Berpijak dari kenyataan tersebut, perlu adanya sebuah upaya terobosan dan alternatif solusi dalam rangka stabilisasi harga komoditas pertanian sekaligus menjaga stok (persediaan) komoditas tersebut. SRG dapat dimanfaatkan oleh petani sebagai bukti kepemilikan komoditas. Selain itu, para pelaku usaha dapat menunda waktu jual hasil panennya pada saat panen raya yang harganya turun menunggu saat yang tepat pada saat yang tepat untuk mendapatkan harga yang lebih baik juga dapat memanfaatkan SRG sebagai agunan untuk mendapatkan kredit dari perbankan.

Dengan demikian, SRG ini oleh banyak kalangan diharapkan menjadi salah satu alternatif sistem pemasaran yang dapat difungsikan sebagai instrumen untuk melindungi petani dari kerugian akibat turunya harga tetapi juga dapat dijadikan sebagai instrumen untuk menjaga stabilitas persediaan pangan nasional. ${ }^{20}$

\section{Kelembagaan Cadangan Pangan Nasional Dalam Perpektif Islam}

Kondisi krisis pangan ini seakan membenarkan pernyataan ekonom klasik, Thomas Robert Malthus (1766-1834) dalam bukunya An Essay on the Principle of Population yang diterbitkan pada 1798. Malthus menyebutkan bahwa pertambahan populasi penduduk akan jauh lebih tinggi dibandingkan

20 Ashari. Prospek Sistem Resi Gudang (SRG) Sebagai Alternatif Pembiayaan Sektor Pertanian, Balitbang Kementan RI, 2010 
dengan kenaikan produksi bahan pangan ${ }^{21}$. Kenaikan harga pangan yang terjadi ini begitu tinggi dan datang secara tiba-tiba serta krisis pangan ini diperkirakan akan berlangsung lama. Jika dianalisis lebih dalam, maka sebenarnya krisis pangan ini terkait dengan masalah struktural yang solusinya harus diupayakan dalam jangka pendek dan jangka panjang. Nilai dasar dari ketahanan pangan sendiri adalah ketersediaan stok pangan dan aksesibilitasnya yang bila dipecah ke dalam sistem perekonomian salah satunya adalah manajemen persediaan. Ironisnya, meningkatnya produksi komuditas pangan di Indonesia tidak di imbangi dengan sistem manajemen stok yang tepat sehingga seakan-akan Indonesia mengalami krisis pangan dikomuditas tersebut.

Sebagai negara agraris, potensi perekonomian Indonesia pada sektor pertanian sangatlah besar. Sekitar $70 \%$ produk domestik bruto Indonesia saat ini dibangkitkan dari konsumsi dalam negeri yang sebagian besar disumbang dari sektor konsumsi pangan. Sebagian besar tenaga kerja Indonesia juga bekerja di sektor produksi pangan. Karena itu, pangan menjadi sektor penggerak utama (growth pole) ekonomi Indonesia. Rakyat Indonesia yang berjumlah besar akan menjadi kekuatan ekonomi jika kebutuhan pangannya bisa dipenuhi dari hasil pertanian dalam negeri, dan akan menjadi pendorong konsumsi. Untuk itu, pemilihan growth pole semestinya ditekankan pada sektor konsumsi pangan, mengingat pangan adalah penggerak utama ekonomi dan penyerap sebagian besar tenaga kerja. ${ }^{22}$

Potensi yang besar tersebut, baik dari sisi SDM maupun SDA sektor pangan tentunya adalah modal utama Indonesia memnuhi kebutuhan pangan warga negaranya agar tercukupi. Ketahanan pangan merupakan salah satu program sosial kemasyarakatan dalam Islam Al Quran sebagai respon dari permaslahan pangan yang dialami oleh masyarakat. Sehingga dengan hadirnya al-Quran, Islam mengajarkan bagaimana ketahanan pangan yang Qurani bisa terwujud. Ketahanan pangan adalah suatu kondisi yang menjamin ketersediaan pangan secara stabil. Islam melalui QS yusuf (12) : 47 menyampaikan bagaimana mengelola pertanian dengan sistem cadangan pangan. Pertanian sebagai aktifitas produksi yang menunjang sumber pangan nabati sehingga ketersediaan pangan dapat terpenuhi. Dengan adanya sistem

${ }^{21}$ Teddy Lesmana dan Ahmad Sofyan, Bangkit di Tengah Krisis Pangan dan Energi, 2008,

h. 1

22 Imam Santoso, "Penyelamatan Ekonomi dengan Strategi Swasembada Pangan", dalam Focus, Edisi 10, April 2003. 
cadangan pangan, diharapkan dapat menanggulangi masalah pangan seperti maslaha kekurangan pangan, gangguan pasokan dan harga dalam keadaan darurat. Tujuan dari pertanian dan cadangan pangan ini adalah tersedianya pangan dalam sedala dimensi waktu.

QS Yusuf ayat 47 memberikan ibroh bagaimana mengelola cadangan pangan untuk antisipasi ketika musim paceklik atau dalam keadaan darurat. Bahwa persediaan yang dipersiapkan untuk masa-masa darurat sesuai dengan ibroh tersebebut juga terkait bagaimana persiapan produksinya baru kemudian disimpan dalam baitul mal yang dikelola oleh kerajaan. Dalam konteks ke-Indonesiaan interpretasi dari sistem manajemen stok ala nabi Yusuf dapat diadopsi dari keberadaan Bulog dan Sistem Resi Gudang.

Bulog dan SRG semangatnya mungkin sama dengan prinsip manajemn stok ala nabi Yusuf hanya saja dalam pelaksananya yang mungkin masih jauh dari nilai-nilai Islam. SRG yang pelaksaanya masih bersinggungan dengan dunia perbankan konvensional, seperti Bank BRI dan Bank BPD. Hal ini tentunya tidak terlepas dari sistem bunga. Sedangkan dalam Islam sistem bunga adalah Riba yang secara mutlak diharamkan. Sistem manajemen stok dengan instrumen SRG sudah saatnya operasional dan pelaksanaanya mulai diIslamkan agar terlepas dari sistem riba.

\section{Penutup}

Pangan Indonesia bukan hanya terbatas pada komoditas beras. Pangan adalah semua kenutuhan yang terkait dengan sumber daya hewani dan nabati untuk memenuhi keberlangsungan hidup manusia. Karenanya kebijakan pemerintah lewat Bulog yang hanya menangani masalah perberasan sudah tidak relevan lagi. Bahwa kenyataan gejolak harga dan pasokan yang banyak terjadi dibeberapa komuditas seperti daging, cabai, bawang merah dan lainya sudah seharusnya pada komuditas-komuditas strategis tersebut harus diatasi dengan campur tangan pemerintah. Gejolak harga dan pasokan seringkali bukan karena terjadi karena kurangnya pasokan tetapi lebih kepada pola manajemen pasca panen dalam setahun yang belum optimal.

Sistem Resi Gudang sebagi instrumen manajemen stok yang cakupanya lebih luas dari pada Bulog juga sudah sepatutnya digenjot terus penerapanya disetiap daerah. Dalam perspektif Islam pengelolaan SRG yang masih bersinggungan dengan transaksi perbankan konvensional yang 
didalamnya terdapat unsur riba tidak mempunyai nafas islam, karenanya semangat manajemen stok pangan yang diajarkan naabi Yusuf seperti bulog harus diperbesar wewenangnya sambil pembenahan sistem SRG agar berjalan dengan perbankan Syariah.

\section{Pustaka Acuan}

Achun, Persediaan.

http://zulidamel.wordpress.com/2008/01/02/persediaan/2008

Ashari. Prospek Sistem Resi Gudang (SRG) Sebagai Alternatif Pembiayaan Sektor Pertanian, Balitbang Kementan RI, 2010

Assauri, sofjan. Manajemen Produksi dan Operasi, Jakarta : Fakultas Ekonomi Universitas Indonesi, 2004

Handewi P.S. Rahman dkk, Kebijakan Pengelolaan Cadangan pangan Pada era Otonomi Daerah dan Perum Bulog. Forum Penelitian Agro Ekonimi IPB. 2005.

Handoko, T Hani, Dasar-Dasar Manajeman Produksi dan operasi, Yogyakarta : BPFE, 2000

Imam Santoso, "Penyelamatan Ekonomi dengan Strategi Swasembada Pangan", dalam Focus, Edisi 10, April 2003.

Indrajit, E,R dan Djopkopranoto.R. Manajemen Persediaan, jakarta : Grasindo.2003

Ishak, Aulia, Manajemen Operasi, yogyakarta : Graha Ilmu, 2010

Muchjidin Rahmat dkk, Kajian Sistem Cadangan Pangan Masyarakat Perdesaan Untuk Mengurangi 25\% Resiko Kerawanan Pangan, Balitbang Deptan RI.2010.

Riswani, Strategi dan Manajemen Pengelolaan Cadangan Pangan Nasional, Prosiding Seminar Nasional, Jurusan Sosial Ekonomi Pertanian Fakultas Pertanian Universitas Sriwijaya, 2010.

Teddy Lesmana dan Ahmad Sofyan, Bangkit di Tengah Krisis Pangan dan Energi, 2008

Wikipedia, Resi Gudang, http://id.wikipedia.org/wiki/Resi Gudang/20/3/2015. 
Yamit, Zulian. Manajemen Persediaan. Yogyakarta : Ekonisia, 2005

Zulfikarijah, Fien, Manajemen Persediaan, malang : Universitas Muhammadiah Malah press, 2005 